\title{
Antimicrobial Activity and Resistance: Influencing Factors
}

\author{
Jun $\mathrm{Li}^{1,2 \dagger}$, Shuyu Xie ${ }^{1,2 \dagger}$, Saeed Ahmed ${ }^{1,2}$, Funan Wang ${ }^{1,2}$, Yufeng $\mathrm{Gu}^{1,2}$, \\ Chaonan $\mathrm{Zhang}^{3}$, Ximan Chai ${ }^{3}$, Yalan $\mathrm{Wu}^{3}$, Jinxia Cai ${ }^{3}$ and Guyue Cheng ${ }^{1,2,3 *}$ \\ ${ }^{1}$ MOA Laboratory for Risk Assessment of Quality and Safety of Livestock and Poultry Products, Huazhong Agricultural \\ University, Wuhan, China, ${ }^{2}$ National Reference Laboratory of Veterinary Drug Residues (HZAU) and MOA Key Laboratory for \\ The Detection of Veterinary Drug Residues in Foods, Huazhong Agricultural University, Wuhan, China, ${ }^{3}$ Basic Veterinary \\ Medicine, College of Veterinary Medicine, Huazhong Agricultural University, Wuhan, China
}

\section{OPEN ACCESS}

Edited by:

Chiranjib Chakraborty

Galgotias University, India

Reviewed by:

Kanagasabai Vadivel,

David Geffen School of Medicine at

UCLA, United States

Nadezhda A. German,

Texas Tech University Health Sciences

Center, United States

*Correspondence:

Guyue Cheng

chengguyue@mail.hzau.edu.cn

${ }^{\dagger}$ These authors have contributed equally to this work.

Specialty section:

This article was submitted to Experimental Pharmacology and Drug

Discovery

a section of the journal

Frontiers in Pharmacology

Received: 23 March 2017

Accepted: 26 May 2017

Published: 13 June 2017

Citation:

Li J, Xie S, Ahmed S, Wang F, Gu Y,

Zhang C, Chai X, Wu Y, Cai J and

Cheng G (2017) Antimicrobial Activity

and Resistance: Influencing Factors.

Front. Pharmacol. 8:364.

doi: 10.3389/fphar.2017.00364
Rational use of antibiotic is the key approach to improve the antibiotic performance and tackling of the antimicrobial resistance. The efficacy of antimicrobials are influenced by many factors: (1) bacterial status (susceptibility and resistance, tolerance, persistence, biofilm) and inoculum size; (2) antimicrobial concentrations [mutant selection window (MSW) and sub-inhibitory concentration]; (3) host factors (serum effect and impact on gut micro-biota). Additional understandings regarding the linkage between antimicrobial usages, bacterial status and host response offers us new insights and encourage the struggle for the designing of antimicrobial treatment regimens that reaching better clinical outcome and minimizing the emergence of resistance at the same time.

Keywords: resistance, persistence, antibiotic concentration, inoculum size effect, serum effect, gut microbiota

\section{INTRODUCTION}

Currently, antibiotics are the invaluable weapons to fight against infectious diseases. However, the outbreak of antimicrobial resistance, jointly with the shortage of newly developed antimicrobial drugs, brings a great threat to the health of both human and animals (Cheng et al., 2016). Rational uses of antibiotics are the key approaches in tackling of the antimicrobial resistance. The effectiveness of antibiotic treatment is determined by many factors, mainly from three aspects, the antibiotic itself, the target pathogen, and the patient body system. In this review, factors influencing the antimicrobial activity have been discussed. These factors include consideration of bacterial status, inoculum size, antibiotic concentrations, serum effect, and interaction with the host gut microbiota. Host dispositions of antibiotics including the metabolism, transport processes, and diffusion between different compartments have been fully discussed in several reviews (Czock et al., 2009; Jarrell et al., 2015), therefore they are not discussed here except the antibiotic-protein binding which leads to the serum effect. These insights could be useful to design more effective clinical antibiotic therapy (Estes, 1998).

\section{BACTERIAL STATUS}

Bacterial status is one of the determinants for antimicrobial activity. The bacterial phenotypes are different under antibiotic exposure, such as susceptibility, resistance, tolerance, and persistence (Brauner et al., 2016).

\section{Susceptibility and Resistance}

Susceptibility and resistance is measured by the minimum inhibitory concentration (MIC). MIC is defined as, the minimum concentration of an antibiotic to inhibit the bacterial growth. MIC is 
usually determined by exposing a defined amount of bacterial population to a series of increasing antibiotic concentrations in a standardized growth medium for about 16-20 h (Wiegand et al., 2008). Isolates can be phenotypically recognized as susceptible and resistant according to the epidemiological cut-off (ECOFF) value or breakpoint (Cheng et al., 2016).

Clinical resistance is a condition in which the clinical criteria of cure did not reached, when a sufficient antibiotic dosage and administration timetable are applied for a specific infection. Clinical resistance is determined by the clinical breakpoints, which separates clinically resistant (related with a high possibility of therapeutic malfunction) from a clinically susceptible bacteria (related with a high possibility of therapeutic victory; Turnidge and Paterson, 2007). Clinical breakpoints are influenced by pharmacokinetic/pharmacodynamic (PK/PD) parameters, which indicate the relationship between antimicrobial activity in vivo and the antibiotic concentration at the site of infection. The PK/PD breakpoint which includes methods of animal models and statistical techniques which indicates a target achievement with a high probability of treatment outcome (Turnidge and Paterson, 2007). Clinical breakpoints are usually defined regarding to the criteria which is established by the Clinical and Laboratory Standards Institute (2011) and the European Committee on Antimicrobial Susceptibility Testing (2011).

\section{Tolerance}

Tolerance is the capacity of a bacteria to stay alive in a fleeting exposure to antibiotics, which applies only to bactericidal antibiotics (Kester and Fortune, 2014). Longer time rather than high concentration of an antibiotic exposure is necessary to construct the same level of killing in a tolerant strain as in a susceptible strain. Tolerant and non-tolerant bacteria may not be different in MIC-value. The minimum duration of killing (MDK) which can be obtained from the time-kill curves are suggested as a quantitative measure of tolerance (Brauner et al., 2016; Table 1, Figure 1). MDK is defined as, the time of an antibiotic treatment essential to kill a known fraction of the bacterial population at an antibiotic concentration that go over the MIC. Likewise to the MIC, that can be used to evaluate the level of resistance between bacterial strains; the MDK can be used to compare the level of tolerance between strains. An evaluation framework that measures both the MDK and the MIC would enable a clear distinction to be made between resistance (an increase in the MIC) and tolerance (an increase in the MDK; Fridman et al., 2014).

There are generally two types of tolerance, "tolerance by slow growth" and "tolerance by lag," the former occurs at stationary phase while the latter occurs in a transient growth arrest often induced by starvation or stress (Brauner et al., 2016). It has long been known that decreased rate of growth increases the bacterial tolerance to some antibiotics, such as $\beta$-lactams and

Abbreviations: ECOFF, epidemiological cut-off; HGT, horizontal gene transfer; IE, inoculum effect; MDK, minimum duration for killing; MIC, minimum inhibitory concentration; MSC, minimal selective concentration; MSW, mutant selection window; MPC, mutant prevention concentration; PK/PD, pharmacokinetic/pharmacodynamics.
TABLE 1 | Difference between resistance, tolerance and persistence.

\begin{tabular}{|c|c|c|c|}
\hline & Resistance & Tolerance & Persistence \\
\hline Heterogeneity & No & No & Yes \\
\hline Inheritability & Yes & Yes or No & No \\
\hline MIC & $\mathrm{MIC}_{\mathrm{R}}>\mathrm{MIC}_{\mathrm{S}}$ & $\mathrm{MIC}_{\mathrm{T}}=\mathrm{MIC}_{\mathrm{S}}$ & $\mathrm{MIC}_{\mathrm{P}}=\mathrm{MIC}_{\mathrm{S}}$ \\
\hline MDK & - & MDKggт > MDKggs & $\begin{array}{l}\text { MDK }_{99 P}=\text { MDK}_{995} \\
\text { MDKg9.99P }> \\
\text { MDK }_{99.99 S}\end{array}$ \\
\hline \multirow[t]{2}{*}{ Form } & - & $\begin{array}{l}\text { 1) Tolerance by slow } \\
\text { growth (High MDK in } \\
\text { stationary and } \\
\text { exponential inocula) } \\
\text { 2) Tolerance by lag } \\
\text { (High MDK only in } \\
\text { stationary inocula) }\end{array}$ & $\begin{array}{l}\text { 1) Time-dependent } \\
\text { persisters a) Persistence } \\
\text { by slow growth b) } \\
\text { Persistence by lag }\end{array}$ \\
\hline & & & $\begin{array}{l}\text { 2) Dose-dependent } \\
\text { persisters }\end{array}$ \\
\hline
\end{tabular}

$M I C$, the minimum inhibitory concentration; $M D K$, the minimum duration for killing; $M D K_{99}$, MDK for $99 \%$ of bacterial cells in the population; MDK ${ }_{99.99}$, MDK for $99.99 \%$ of bacterial cells in the population; s, Susceptible; $R$, Resistant; $T$, Tolerant; $p$, Persistent.

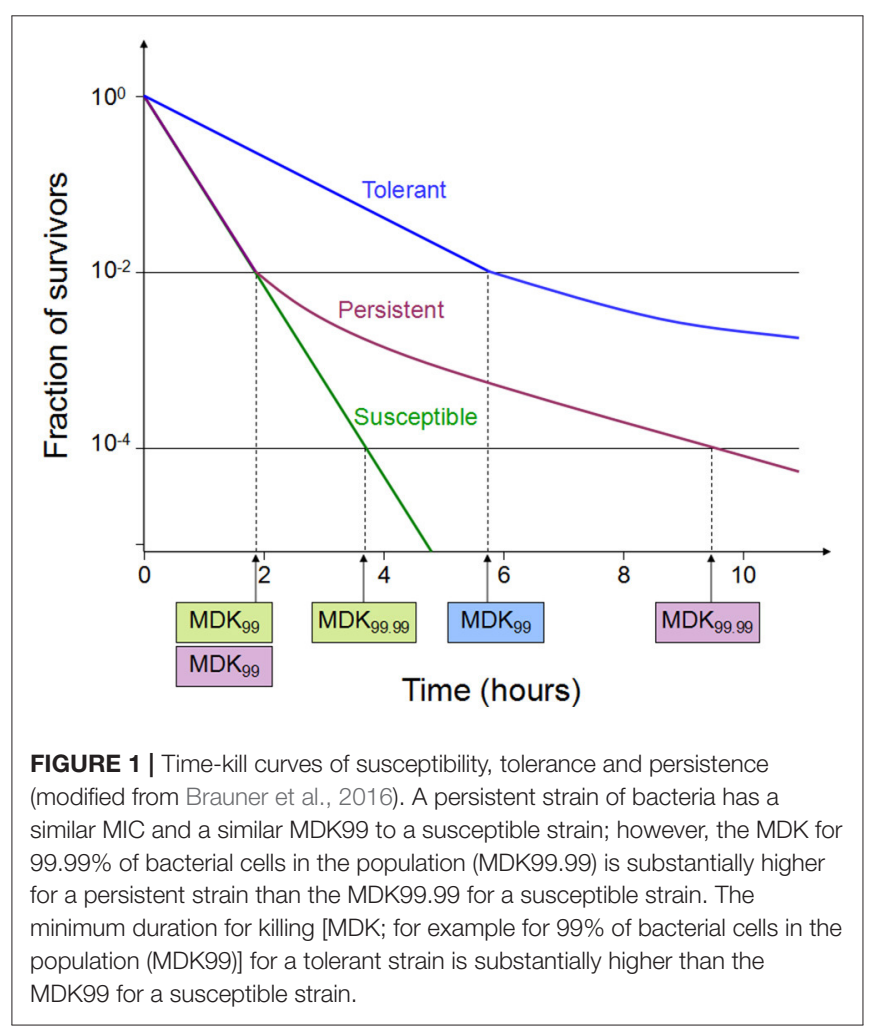

fluoroquinolones. The actions of these drugs require for bacterial growth. "Tolerance by slow growth" may be inherited in some bacterial species, such as Mycobacterium tuberculosis (Manina et al., 2015), or non-inherited when the growth of bacteria is damaged by a specific poor conditions (e.g., location in biofilm, exposure to inhibitors; Bernier et al., 2013) and the host factors (Helaine et al., 2010).

The lag phase is the time that growth-arrested bacteria restart the exponential growth when expose to a growth-permissive 
environment (e.g., bacteria enter into the host environment or control between different niches; Amato et al., 2013). In lag phase the bacterial cells initially adapted the new circumstance before resuming the exponential growth (Madar et al., 2013). Tolerance by lag phase occurs when the duration of the growth arrest is longer than the antibiotic treatment time (Balaban et al., 2004). Tolerance by lag phase can reach an MDK of many hours or days (Fridman et al., 2014). Inherited tolerance by lag phase includes many mutations and a number of toleromerelated genes which are more than resistome-related genes (Girgis et al., 2012), suggesting that the development of high tolerance may take place faster than the evolution of high resistance.

\section{Persistence}

Persistence occurs in a bacterial subpopulation (classically $<1 \%$ ) that are not killed by antibiotics, and heterogeneous response is repeated when they are expose to the same antibiotic (Lewis, 2007). The detection of persisters requires different percentile for the MDK measurement, usually using the $\mathrm{MDK}_{99.99}$ (time of treatment duration required to kill $99.99 \%$ of a bacterial population; Brauner et al., 2016; Table 1, Figure 1). Dormant persisters are found to be present in a mouse models infected by S. typhimurium (Helaine et al., 2010) or M. tuberculosis (Manina et al., 2015). Time-dependent persistence is defined as the bacteria which typically has either a longer lag time or slower growth rate than the majority of the population (Balaban et al., 2004). The molecular mechanisms of time-dependent persistence are also associated with tolerance that slows down the killing by antibiotics (Adams et al., 2011).

MDK provide an apparent predictions of the treatment period that is needed to treat an infection by strains with the tolerance or time-dependent persistence, and could thus be combined with $\mathrm{PK} / \mathrm{PD}$ models to optimize treatment regimens (Brauner et al., 2016). However, in some case of the tolerance with very high MDK, the antibiotic toxicity to host may limit the treatment duration. Dose-dependent persistence might be treated with inhibitors, such as efflux pump inhibitors (Adams et al., 2014).

Drug-induced tolerance or persistence which causes growtharrest in some of the microorganisms may results in a long MDK (Dorr et al., 2010; Johnson and Levin, 2013). Survival of the bacterial population under antibiotics may facilitate the subsequent emergence of resistance, e.g., increase the mutation rates. Understanding the bacterial survival strategies gives a better understanding of how bacteria evolve resilience to antimicrobials (Cohen et al., 2013).

\section{Biofilm}

Microorganisms can grow up in a free-living (planktonic) or in a cell aggregates (biofilm). Biofilms are consortium of bacteria, which are surrounded in a self producing polymer matrix which consist of a polysaccharides, proteins and DNA (Hall-Stoodley et al., 2012). Host factors such as platelets, immunoglobulin, and fibrin, may also be included into the extracellular matrix (Akiyama et al., 1997). Antimicrobial resistance can emerge in a biofilms by at least three different mechanisms: (1) impair the antibiotics diffusion of into the surrounded bacterial cells by extracellular matrix; (2) lesions in the mismatch repair system or in the DNA oxidative repair system resulting in hypermutator; and (3) emergence of persistent bacterial cells (Penesyan et al., 2015). High cell density in a biofilms may increase the number of resistant mutants that can be selected under antibiotic pressure and the extracellular DNA in biofilm matrix can facilitate horizontal gene transfer of resistance determinants (Cheng et al., 2016). Based on the results of in vitro studies of Yonezawa et al. (2015), Helicobacter pylori biofilm formation can reduce sensitivity to antibiotics and resistance mutations are more often generated in a biofilms than in a planktonic cells. Zhang et al. examined the correlation between biofilm and antibiotic resistance among 110 strains of clinical isolates of Haemophilus parasuis. The results indicated that $H$. parasuis field isolates have the capability to form biofilms in vitro. In addition, biofilm positive strains have a positive association with a resistance against $\beta$-lactams antibiotics and may play an important role in H. parasuis infections (Zhang et al., 2014). Using an Escherichia coli biofilm model, Tyerman et al. demonstrated that a heritable variation for the broad-spectrum antibiotic resistance can arise and accumulate rapidly during biofilm development, even in the absence of antibiotic selection (Tyerman et al., 2013). A study by Bae et al. reported that Campylobacter jejuni transfers antibiotic resistance genes more frequently in biofilms than in planktonic cells by natural transformation (Bae et al., 2014).

Molecular and structural understanding of biofilm has led to the advances in targeting the specific biofilm determinant mechanism, such as anti-adhesion, targeting signaling pathways, dispersing biofilm matrix, and eliminating persisters, which could be applied in a combination with the antibiotic therapy (Cheng et al., 2014, 2016).

\section{BACTERIAL INOCULUM SIZE}

Inoculum effect is defined as an increase in the MIC with increasing bacterial inoculum size (Brook, 1989). If there is an inoculum effect, bacteria might appear as a susceptible when the inoculums is standard $\left(10^{5} \mathrm{CFU} / \mathrm{ml}\right)$ but resistant if the inoculum size is increased. Several studies have been shown that high bacterial inocula at the infection sites may decrease the activity of antibiotic (Table 2). The mechanisms underlying the inoculum effect may be reduced ratio of available drug molecules per target because of reduced effective antimicrobial concentration (Udekwu et al., 2009). Inoculum size is also important in the emergence of an antibacterial resistance. At marbofloxacin concentrations within the MSW, the appearance of $E$. coli mutants resistant to marbofloxacin was more frequent when the initial size of the bacterial population was increased, indicating that the process of a mutant selection within the MSW was influenced by the presence of mutants before any antibiotic treatment (Ferran et al., 2007).

Another reason for inoculum effect regarding the reducing of antibiotic potency is due to the self-limiting of a bacterial growth in the high inoculum size which may increase bacterial tolerance to some antibiotics or the presence of heterogeneity 
TABLE 2 | Recent studies on inoculum size effect of antibiotics.

\begin{tabular}{|c|c|c|c|}
\hline Bacteria & Inoculum size & MIC Change & References \\
\hline $\begin{array}{l}\text { E. coli ATCC } 25922 \text { (non-ESBL } \\
\text { producer) E. coli Ec1062 } \\
\text { (CTX-M-14 producer) }\end{array}$ & $\begin{array}{l}10^{5.5} \mathrm{CFU} / \mathrm{g} \text { and } \\
10^{7.5} \mathrm{CFU} / \mathrm{g}\end{array}$ & $\begin{array}{l}\text { In an experimental murine sepsis model, piperacillin-tazobactam and imipenem } \\
\text { reduced spleen ATCC } 25922 \text { strain concentrations }(-2.53 \text { and }-2.14 \text { log10 CFU/g } \\
{[P<0.05 \text {, respectively]) in the HI vs. LI groups, while amoxicillin-clavulanate }} \\
\text { maintained its efficacy }(-1.01 \text { log10 CFU/g [no statistically significant difference]). } \\
\text { Regarding the Ec1062 strain, the antimicrobials showed lower efficacy in the HI than } \\
\text { in the LI groups: }-0.73,-1.89 \text {, and }-1.62 \text { log10 CFU/g }(P<0.05 \text {, for } \\
\text { piperacillin-tazobactam, imipenem, and amoxicillin-clavulanate, respectively, although } \\
\text { imipenem and amoxicillin-clavulanate were more efficacious than } \\
\text { piperacillin-tazobactam). }\end{array}$ & $\begin{array}{l}\text { Docobo-Perez et al., } \\
2013\end{array}$ \\
\hline E. coli & $\begin{array}{l}5 \times 10^{2} \text { to } 5 \times \\
10^{8} \mathrm{CFU} / \mathrm{ml}\end{array}$ & $\begin{array}{l}\text { The concentrations of marbofloxacin needed to eradicate all bacterial population } \\
\text { increased from } 1 \text { - or } 2 \text {-fold the MIC for low inocula to } 128 \text { - or } 256 \text {-fold the MIC for the } \\
5 \times 10^{7} \text { and } 5 \times 10^{8} \mathrm{CFU} / \mathrm{ml} \text { inocula. }\end{array}$ & Ferran et al., 2014 \\
\hline \multirow[t]{2}{*}{ MSSA \& MRSA } & $\begin{array}{l}2.5-4 \times 10^{2} \text { to } \\
2.5-4 \times 10^{6} \\
\text { CFU/spot }\end{array}$ & $\begin{array}{l}\text { To MSSA, a big IE for ampicillin; small IE for cefazolin, meropenem, and ciprofloxacin; } \\
\text { middle IE for teicoplanin and linezolid. }\end{array}$ & Miyake et al., 2011 \\
\hline & & $\begin{array}{l}\text { To MRSA, small change in vancomycin and arbekacin; middle change in teicoplanin } \\
\text { and linezolid. }\end{array}$ & \\
\hline MRSA & $\begin{array}{l}10^{4}, 10^{6}, \text { and } 10^{8} \\
\mathrm{CFU} / \mathrm{ml}\end{array}$ & $\begin{array}{l}\text { A small IE for vancomycin ( } \mathrm{MIC} L=1 \mathrm{mg} / \mathrm{ml}, \mathrm{MIC}_{\mathrm{M}}=1-2 \mathrm{mg} / \mathrm{ml} \text {, and } \mathrm{MIC}_{\mathrm{H}}=2 \\
\mathrm{mg} / \mathrm{ml}) ; \text { a significant IE for daptomycin ( } \mathrm{MIC} \mathrm{C}_{\mathrm{L}}=0.25 \mathrm{mg} / \mathrm{ml}, \mathrm{MIC}_{\mathrm{M}}=0.25-0.5 \\
\left.\mathrm{mg} / \mathrm{ml} \text {, and } \mathrm{MIC}_{\mathrm{H}}=2 \mathrm{mg} / \mathrm{ml}\right) ; \text { no } \mathrm{IE} \text { for linezolid at low and medium inocula ( } \mathrm{MIC}= \\
\left.1 \mathrm{mg} / \mathrm{ml} \text { and } \mathrm{MIC}_{\mathrm{M}}=1-2 \mathrm{mg} / \mathrm{ml}\right) \text {, but with the high inoculum, concentrations up to } \\
2,048 \mathrm{mg} / \mathrm{ml} \text { did not fully inhibit visual growth. }\end{array}$ & $\begin{array}{l}\text { Rio-Marques et al., } \\
2014\end{array}$ \\
\hline $\begin{array}{l}\text { Staphylococcus aureus } \\
\text { Pseudomonas aeruginosa }\end{array}$ & $10^{5}-10^{8} \mathrm{cfu} / \mathrm{mL}$ & $\begin{array}{l}10^{5} \sim 10^{8} \mathrm{cfu} / \mathrm{mL} \text { had no significant effect on the MICs of fluoroquinolones and } \\
\text { carbapenems; however, inoculum size to }>10^{8} \mathrm{cfu} / \mathrm{mL} \text { resulted in a reduction in } \\
\text { bactericidal activity against } S \text {. aureus; increasing the inoculum size of } P \text {. aeruginosa } \\
\text { exerted only a minimal influence on the bactericidal activity of fluoroquinolones, but } \\
\text { resulted in a reduction in the bactericidal activity of carbapenems; when the inoculum } \\
\text { was increased above } 10^{6} \mathrm{cfu} / \mathrm{mL} \text {, the duration of the PAEs of these antimicrobial } \\
\text { agents was reduced; Inoculum size had a greater influence on the in vivo efficacy of } \\
\text { carbapenems than that of fluoroquinolones in mouse model. }\end{array}$ & $\begin{array}{l}\text { Mizunaga et al., } \\
2005\end{array}$ \\
\hline$P$. aeruginosa & $\begin{array}{l}10^{6}, 10^{8}, \text { and } 10^{9} \\
\mathrm{CFU} / \mathrm{ml}\end{array}$ & $\begin{array}{l}\text { The killing of the susceptible population was } 23 \text {-fold slower at the } 10^{9} \mathrm{CFU} / \mathrm{ml} \text { and } \\
6 \text {-fold slower at the } 10^{8} \mathrm{CFU} / \mathrm{ml} \text { than at the } 10^{6} \mathrm{CFU} / \mathrm{ml} \text {. }\end{array}$ & Bulitta et al., 2010 \\
\hline $\begin{array}{l}\text { Staphylococus spp } \\
\text { Streptococcus spp. } \\
\text { Enterobacteriaceae } P \text {. } \\
\text { aeruginosa }\end{array}$ & $\begin{array}{l}5 \times 10^{3}, 5 \times 10^{5} \\
\text { and } 5 \times 10^{7} \\
\mathrm{CFU} / \mathrm{ml}\end{array}$ & $\begin{array}{l}\text { An increase over } 7 \text {-fold of the MIC in ozenoxacin, ciprofloxacin, and levofloxaci at } 10^{7} \\
\text { CFU/mL }\end{array}$ & Tato et al., 2014 \\
\hline Pasteurellaceae & $\begin{array}{l}5 \times 10^{5} \text { and } 5 \times \\
10^{8} \mathrm{CFU} / \mathrm{ml}\end{array}$ & $\begin{array}{l}\text { Marbofloxacin was equally potent against } 10^{5} \mathrm{CFU} / \mathrm{mL} \text { inocula Mannheimia } \\
\text { haemolytica and Pasteurella multocida; an IE was observed with } P \text {. multocida at a } \\
10^{8} \mathrm{CFU} / \mathrm{mL} \text { inoculum; no IE was observed with } \mathrm{M} \text {. haemolytica. At the same dose, } \\
\text { the clinical and bacteriological outcomes were much better for mice infected with } \mathrm{M} \text {. } \\
\text { haemolytica than for those infected with } P \text {. multocida with } 10^{9} \mathrm{CFU} \text { of each bacteria }\end{array}$ & Lhermie et al., 2015 \\
\hline Klebsiella pneumoniae & $\begin{array}{l}10^{5} \mathrm{CFU} \text { or } 10^{9} \\
\text { CFU/animal }\end{array}$ & $\begin{array}{l}\text { The dose of } 50 \mathrm{mg} / \mathrm{kg} \text { b.w. cefquinome targeting the high } \mathrm{K} \text {. pneumoniae inoculum } \\
\text { cured all the treated rats and resulted in a massive amplification of CTX-M-producing } \\
\text { Enterobacteriaceae. A dose of } 5 \mathrm{mg} / \mathrm{kg} \text { targeting the low } \mathrm{K} \text {. pneumoniae inoculum } \\
\text { cured all the rats and averted an outbreak of clinical disease, all without any } \\
\text { amplification of CTX-M-producing Enterobacteriaceae. }\end{array}$ & Vasseur et al., 2014 \\
\hline
\end{tabular}

ESBL, extended-spectrum $\beta$-lactamase; MSSA, methicillin-susceptible Staphylococcus aureus; MRSA, methicillin-resistant Staphylococcus aureus; IE, inoculum effect.

resistant persisters in such inocula. When $5 \times 10^{3} \mathrm{CFU} / \mathrm{ml}$ of gyrA mutant $E$. coli were mixed with $5 \times 10^{7} \mathrm{CFU} / \mathrm{ml}$ of wild-type bacteria, MPC could eradicate both of the bacteria; whereas when $5 \times 10^{3} \mathrm{CFU} / \mathrm{ml}$ of gyrA mutant $E$. coli were mixed with a $1-\log _{10}$ higher inoculum $\left(5 \times 10^{8} \mathrm{CFU} / \mathrm{ml}\right)$ of wildtype bacteria, the mutants were not eliminated when expose to antibiotic concentrations above the MPC (Ferran et al., 2014). Lee et al. (2010) suggests that a small number of bacterial resistant mutants can provide the protection to others by producing signaling molecule indol to turn on the drug efflux pumps and oxidative-stress protective mechanisms, enhancing the survival capacity of the overall population.

Inoculum size could have considerable affect on the pharmacokinetic/pharmacodynamic parameters of antibiotics. In a mouse thigh model challenged with either a high $\left(10^{8} \mathrm{CFU}\right)$ or a low $\left(10^{5} \mathrm{CFU}\right)$ inoculum of $E$. coli, the values of time within the mutant selection window $\left(T_{\mathrm{MSW}}\right)<30 \%$ appeared to be a good predictor for prevention of a resistance (Ferran et al., 2009). When the time within the MSW was higher than $34 \%$, the selection of resistant bacteria occurred more often in thighs 
initially infected with the high inoculum (80\%) than in those infected with the low inoculum (46\%; Ferran et al., 2009). In another study, a rat lung infection model was challenged with a low $\left(10^{5} \mathrm{CFU}\right)$ or a high $\left(10^{9} \mathrm{CFU}\right)$ inoculum of Klebsiella pneumonia, the results displayed that for the low inoculum, prevention of resistance occurred for an AUC/MIC ratio of 189 $\mathrm{h}$, while for the high inoculums, resistant bacteria were enriched for AUC/MIC ratios up to $756 \mathrm{~h}$ (Kesteman et al., 2009). For rats infected with a high inoculums size, the parameters of AUC/MIC, $C_{\max } / \mathrm{MIC}$, and $T_{\mathrm{MSW}}$ were not found to be effective predictors for the resistance prevention. They proposed an original index, the $T_{>\text {MPC }} / T_{\text {MSW }}$ ratio, which reflects the ratio of the time that the less susceptible bacterial subpopulation is killed over the time that it is selected and this ratio is valid only if the plasma concentrations achieve the MPC (Kesteman et al., 2009).

Different antibiotics show different inoculum effects on the growth and selection of resistance of the same strain. A small inoculum effect was observed for vancomycin and a significant inoculum effect for daptomycin in methicillinresistant Staphylococcus aureus (MRSA), while linezolid exhibited no inoculum effect at low and medium inocula $\left(10^{4}\right.$ and $\left.10^{6} \mathrm{CFU} / \mathrm{ml}\right)$ but with the high inoculum $\left(10^{8} \mathrm{CFU} / \mathrm{ml}\right.$; (Rio-Marques et al., 2014)). After incubation with either drug at 2-fold increasing concentrations for 15 days, MICs of low, medium, and high inocula to vancomycin were $2-4,4-8$, and $4-16 \mathrm{mg} / \mathrm{L}$ and for daptomycin were $0.5 \sim 2,8 \sim 128$, and $64 \sim 256$ $\mathrm{mg} / \mathrm{L}$, respectively (Rio-Marques et al., 2014). In addition, one antibiotic may show differential inoculum effect against different strains. It was demonstrated that marbofloxacin was equally potent against $10^{5} \mathrm{CFU} / \mathrm{ml}$ inocula of Mannheimia haemolytica and Pasteurella multocida. However, an inoculum effect was observed with $P$. multocida, whereas there was no inoculum effect for M. haemolytica (Lhermie et al., 2015). The in vivo mice model infected with $10^{9} \mathrm{CFU}$ of each bacteria also showed that the clinical outcomes of marbofloxacin were much better for mice challenged with $M$. haemolytica than those infected with $P$. multocida (Lhermie et al., 2015).

In order to summarize, for the bacterial populations of high inoculum, both wild-type and resistant bacteria are with very low rates of division, therefore the antimicrobial activity is dramatically reduced and targeting the mutant bacteria to improve the clinical outcomes in a patients is not enough (Ferran et al., 2014). In a clinical settings, there is a need for a prompt antibiotic treatment to minimize the inoculum size. Meanwhile, strategies aimed at lowering the inoculum size at the infection site should be used whenever possible in parallel to antimicrobial therapy (Rio-Marques et al., 2014). This highlights the importance of surgical drainage or infection source removal in high bacterial density infections (Entenza et al., 2010). Moreover, bacterial species-specific antibiotic dosing schedules is needed in a clinical settings (Lhermie et al., 2015).

\section{ANTIBIOTIC CONCENTRATIONS}

The antibiotics apply its effect by different mechanisms, initially by inhibiting the synthesis of the bacterial wall (penicillins, glycopeptides, carbapenems, and cephalosporins), inhibiting DNA replication (quinolones) or its transcription (rifampicin), impairing bacterial ribosomes and protein synthesis (macrolides, linezolid, dalfopristin, tetracyclines, and aminoglycosides), interfering with metabolic pathways (sulfonamides and trimethoprim) or disrupting the cytoplasmic membrane (polymyxin and daptomycin; Zamoner et al., 2016). Different antibiotic concentrations may results in a different selection of the resistant bacteria, thus influencing the efficacy of antimicrobials.

\section{Mutant Selection Window (MSW)}

The antimicrobial choices enrich the resistance genes which are already present earlier than selection operates in a particular setting. Susceptible population will be inhibited at an antibiotic concentration above the MIC. Resistant isolates should be inhibited by a higher concentration (i.e., the MICs of the resistant mutants). Mutant selection window (MSW) is a collection of concentrations between the MICs of the susceptible and resistant variants. Resistant mutants may be selected under antimicrobial selective pressures in the MSW (Drlica, 2003). The upper boundary, defined as the mutant prevention concentration (MPC), can inhibit the growth of the entire bacteria population (Drlica and Zhao, 2007). Determination of MPC needs a large inoculum (approximately $10^{9} \sim 10^{10} \mathrm{CFU} / \mathrm{ml}$ ) compared to MIC testing $\left(10^{5} \mathrm{CFU} / \mathrm{ml}\right.$; Blondeau, 2009). This high inoculum is applied to ensure the emergence of the first-step mutants. The MPC concept can also be applied to higher-order mutants.

The MSW concept aims to the prevention of a resistance. When the pertinent antimicrobial agent is present at a concentration within the MSW, a selection process of resistance will occur. Therefore, dosages ensuring antibiotic concentrations at the infection site above the MPC are suggested. The emergence of resistant bacteria is a dynamic phenomenon over time, the MPC should be established with new PK/PD knowledge (Mouton et al., 2011). And also high doses may impose a potential toxicity to human or animals thus its limits the clinical usage of the MPC concept.

\section{Sub-inhibitory Concentrations}

Antibiotic at sub-inhibitory concentrations are found in many of the natural environments, such as soil and water, they are also generated as a consequence of antibiotic therapy in a humans and livestock, such as suboptimal dosing therapy, poor pharmacokinetics, usage of low-quality drugs, and a poor patient compliance (Andersson and Hughes, 2014). In agricultural sector, antibiotics are often administered as a feed additives to promote growth of animals, the doses are typically subtherapeutic and often result in a concentrations below the MIC (Wallinga and Burch, 2013), which is termed as sub-MIC concentrations. This concentration allows susceptible strains to continue growing at a reduced growth rate.

Recent investigation have been shown that sub-MIC concentrations of antibiotic can be choose for a low-level of resistance, which eventually serve as a stepping stones paving the way for high-level resistance (Baquero et al., 1998; Baquero, 2001). Two recent studies investigated the selective potential 
of sub-MIC concentrations (Gullberg et al., 2011; Liu et al., 2011). In one of the experiment, researchers mixed wild-type and isogenic resistant bacterial strains with a single resistance mutation or resistance gene at an initial mutant/wild type ratio of 1/1 (Gullberg et al., 2011). As shown in Figure 2, in the antibiotic absence, wild-type strain had a competitive advantage against the resistant strain (due to fitness cost of particular resistance determinant). Though the antimicrobial concentration increased, a progressive shift has been started in the selection toward the isogenic resistant strain. The lowest antimicrobial concentration is needed to choose for the resistant mutant over the wild type is called as the minimal selective concentration (MSC). Selection for the resistant mutants also occurs at a concentrations of the sub-MIC selective window (between the MSC and the MIC of the susceptible strain; Figure 2; Gullberg et al., 2011).

Except for enriching of pre-existing resistant variants, subMIC concentration can also select for de novo resistance by increasing the rate of adaptive evolution, including a resistance development. Several classes of antibiotics at a sub-MIC levels (such as fluoroquinolones, $\beta$-lactams, and aminoglycosides) have been reported to be able to induce the SOS response and the RpoS regulon in bacteria (Gutierrez et al., 2013), which can leads to a genetic alterations including movement of mobile elements that may carry resistance or virulence determinants (Beaber et al., 2004; Ubeda et al., 2005), activation of recombinases (Lopez et al., 2007; Lopez and Blazquez, 2009), and increase in the rate of mutagenesis during chromosome replication (Kohanski et al., 2010; Baharoglu and Mazel, 2011; Thi et al., 2011).

In addition, it has been shown that antibiotic-associated signaling can influence the resistance development in a bacterial population (Lee et al., 2010). Such signaling resulted in a several functional consequences including the induction of conjugative transfer, gene expression, quorum sensing, biofilm

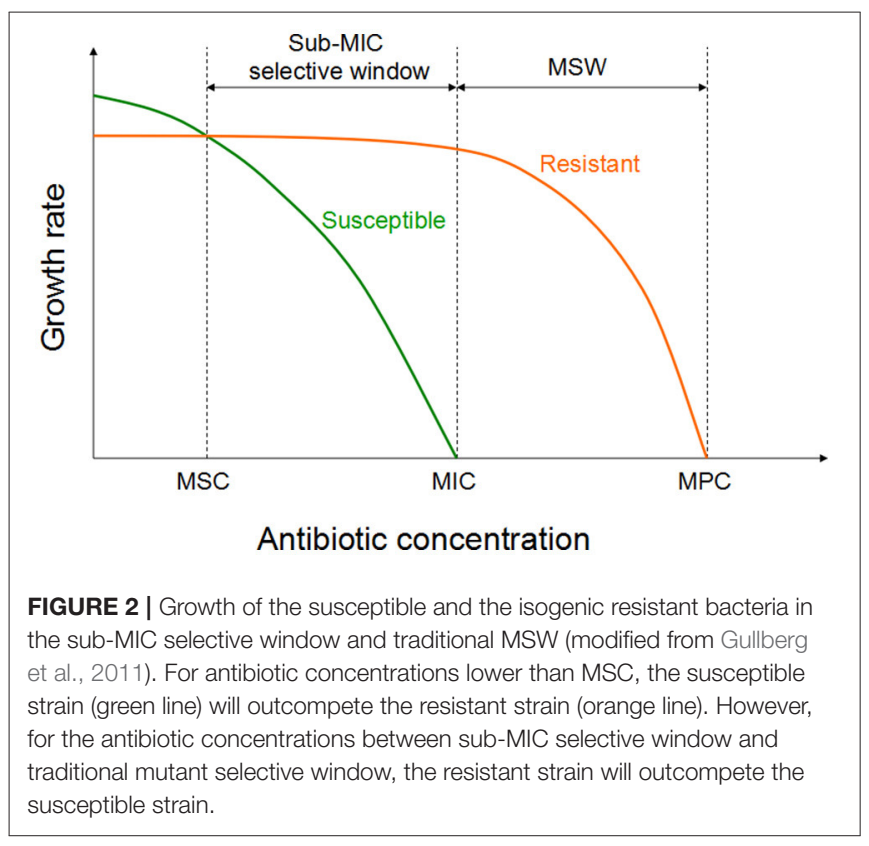

formation and bacterial virulence (Yim et al., 2007; Dietrich et al., 2008; Fajardo and Martinez, 2008; Romero et al., 2011). A study showed that under an increasing concentrations of norfloxacin, highly resistant $E$. coli population excreted indole as a signaling molecule to the susceptible population, which cause the susceptible strains to up regulate the efflux pump expression, resulting in a population-wide resistance (Lee et al., 2010). Although, there is no evidence that the antibiotic itself can function as a signal, but it led to the selection of bacteria that can produce signal, which, in turn, increased an MIC of the entire population (Andersson and Hughes, 2014).

\section{SERUM EFFECT}

Increase of the MIC due to the antibiotics highly bound to proteins in the serum is a phenomenon that has been investigated not only for some old small molecular antibiotics such as cefonicid, cefoperazone, and ceftriaxone (Chambers et al., 1984; Jones and Barry, 1987; Lam et al., 1988) but also for newly developed antibiotics (Kaplan et al., 2013) as well as for the peptides antibiotics such as daptomycin (Lee et al., 1991) and vancomycin (Dykhuizen et al., 1995). It has been documented that only the non-protein-bound fraction of an antimicrobial is microbiologically active (Beer et al., 2009) and drugs with the higher protein binding typically display higher modifications of in vitro activity in the presence of human serum (Zeitlinger et al., 2011).

Different antibiotics in the same class may show different serum effects. MICs of ceftriaxone in the presence of human serum were 4- to 8-fold higher than the those obtained in a broth (Jones and Barry, 1987). while, the bactericidal activity of cefotaxime, desace tylcefotaxime, and cefotaxime plus desacetylcefotaxime were slightly improved in human serum (Jones and Barry, 1987). The activity of ozenoxacin, a new desfluoro-(6)-quinolone, decreased by increasing the presence of human serum in the medium, but no significant effects with ciprofloxacin and levofloxacin were found (Tato et al., 2014). This is because that most of the fluoroquinolones exhibit low protein binding, ranging from $\sim 20$ to $40 \%$ in serum (Bergogne-Berezin, 2002), but ozenoxacin exhibited high protein binding, ranging from 85.2 to $86.7 \%$ independent of concentration (Tato et al., 2014).

In some of the cases, serum could also display a paradoxical effect on the antibiotic activity. The activity of amphotericin B against C. albicans ATCC 24433 was potentiated in RPMI medium in small amounts of the serum, while attenuated at higher concentrations of serum (Richie et al., 2012). This is also the same case for lantibiotic MU1140 against S. aureus, with the maximum bactericidal effect at $25 \%$ serum concentration (Ghobrial et al., 2010).

The serum effect of the same antibiotic varies between microorganisms. The activity of lantibiotic MU1140 against $S$. pneumonia was inhibited in serum, while it was found to be enhanced against S. aureus (Ghobrial et al., 2010). Hypothetically, the augmentation of antimicrobial activity for $S$. aureus could be due to the interaction of serum components with specific 
extracelluar sites on $S$. aureus, thus acting as a docking site for MU1140 and facilitating the MU1140-lipid II interaction (Ghobrial et al., 2010). The effects of serum on the activity of azoles and amphotericin B reported is also varied, depending upon the fungal strains used (Zhanel et al., 2001).

Although the changes in the antimicrobial activity have been studied at a wide range of serum concentrations (20-100\%) in test medium (Zhanel et al., 2001), it should be noted that bacterial growth may be inhibited even at serum concentrations below 50\% (Nix et al., 2004). Components such as complement factors transferring and properdin in native serum, might provoke the complex and unpredictable inhibition of bacterial growth (Furbeth and Adam, 1976).

Living systems are a dynamic compared to static in vitro tests (Smith et al., 2010), therefore, the results of in vitro experiments always require to be assured in in vivo settings. For example, telavancin, a glycopeptides, although the protein binding was above $90 \%$ and in vitro studies observed a 10 fold decline of the activity in the presence of proteins; it was recently permitted on clinical base efficacy (Hegde et al., 2004; Stryjewski et al., 2008). Models should be conducted to mimic physiological states as closely as possible to enable the extrapolate data from a numerous models to in vivo state. The establishment of a methods for a direct quantification of affinity of protein binding or its reversibility in individual models may leads to a better understanding of the results where the free drug hypothesis contradict (Zeitlinger et al., 2011).

\section{INTERACTION WITH THE GUT MICROBIOTA}

The intestinal microbiota protects the hosts against infections and other pathologies by directly inhibiting colonization of invading microbes or by orchestrating appropriate immune responses, which can control innate and adaptive immunity in the gut (Macpherson et al., 2012; Kabat et al., 2014; Becattini et al., 2016). Commensal bacteria ferment plant-derived fibers producing short-chain fatty acids that feed enterocytes and modulate immune functions, and some of the commensal bacterial species which have the ability to synthesize the essential vitamins that are important for the growth and function of the immune cells (Brestoff and Artis, 2013).

In food producing animals, the most common route of antibiotic administration is oral. However, oral antibiotic administration may results in a gut microbiota dysbiosis, which remains for a long periods of time, spanning months, and even years (Francino, 2015; Gasparrini et al., 2016). Antibiotic treatment during the early postnatal period is one of the most important factors that can influence the maturation of the infant gut microbiota and thus increase the risk of a disease (Cox et al., 2014; Rutten et al., 2015). The usage of antibiotic is found to lead into a reduction in species richness and treatment with specific antibiotics resulted in an enrichment of specific sets of antibiotic resistance genes that are associated with a single species (Gibson et al., 2016; Korpela et al., 2016).
The antibiotics induced microbiota alterations can affect the basic immune homeostasis, especially if they occur early in life, which is an important period for maturation of the immune system and establishment of immunological tolerance (Francino, 2014). The human intestinal microbiota has been recognized as an important reservoir of antimicrobial resistances (Ghosh et al., 2013; Field and Hershberg, 2015; Gasparrini et al., 2016).

Gut microbiota alterations may also increase the sensitivity to infections, which can stem from a lately invaded pathogens or from the abrupt overgrowth and pathogenic actions of the opportunistic organisms which are already exist in the gut (Young and Schmidt, 2004; Sekirov et al., 2010). Besides altering the composition of taxa, antibiotics can also affect the expression of gene, protein activity, and overall metabolism of the gut microbiota (Franzosa et al., 2015). For example, streptomycin generates galactarate and glucarate in the lumen by enhancing the production of host-derived reactive nitrogen species, thereby providing Enterobacteriaceae with a fitness advantage (Faber et al., 2016).

On the other hand, some of the antibiotics, except for antimicrobial activity, exhibit immunomodulatory properties. The 14- and 15-member macrolides can interact with mitogenactivated protein kinases, thereby inhibiting NF- $\kappa$ B-mediated inflammatory responses toward various stimuli (Woodhead et al., 2011). Fluoroquinolones exhibiting a cyclopropyl moiety at position $\mathrm{N} 1$ of the quinolone core structure may exert antiinflammatory effects besides their well-established antimicrobial properties (Dalhoff, 2005). Enrofloxacin shows potential effect of on the development of a protective immune response against $H$. parasuis infection (Macedo et al., 2015).

\section{CONCLUSIONS AND PERSPECTIVES}

Rational and correct uses of antibiotics are the key approaches in improving antibiotic performance and tackling the antimicrobial resistance. The efficacy of an antibiotic treatment is influenced by many factors. The sensitivity of the specified pathogens is usually combined with pharmacokinetic parameters to investigate the effectiveness of antimicrobial dosage regimens. It should be noted that only the non-protein-bound fraction of an antibiotic is microbiologically active in vivo, which makes the serum effect to be considered in an antibiotic therapy. Choosing the precise antibiotic is important, as the serum effect is changed between different antibiotics in the same class or one antibiotic against different microorganisms. Since living systems are more dynamic and complex, the results of in vitro tests always necessitate to be assured in in vivo settings.

On the other hand, MIC is not informative for some special bacterial status, such as persistent or tolerant bacteria. In contrast to infections caused by planktonic bacteria, biofilm-forming bacteria tend to cause the chronic infections, especially in the respiratory tract, whereby infections persist despite seemingly adequate antibiotic therapy. This is because emergence of persistent or the tolerant bacterial cells is usually happened in biofilms. Recently, several compounds have been identified as 
an effective against time-dependent persisters (Kim et al., 2011) or against tolerance in biofilms (Fleck et al., 2014) through the method of systematic screens; however, the effectiveness of these compounds has not yet been assessed in the clinical settings. In addition, some existing antibiotics have been found to be less prone to tolerance, such as daptomycin (Mascio et al., 2007).

Antibiotic regimens should be optimized not only for the treatment outcome, but also for the minimization of antimicrobial resistance development (Mouton et al., 2011). When using antibiotics in clinic, there is a requirement for a prompt antimicrobial treatment, which would inhibit the inoculums size enlargement at infection site, as well as for the antibiotic regimens precluding a prolonged period of time within the MSW. Recent studies have also been shown that sub-MIC concentrations can select for resistant mutants. Therefore, we should reduce or prohibit the sub-therapeutic use of antibiotics as the growth promoters or for prophylaxis purposes as much as possible in animal production.

It should not be ignored that antibiotic induced alterations in composition and functions of the microbiota may also create long-lasting harmful effects for the host and increase the bacterial resistance (Francino, 2015; Becattini et al., 2016). Selection of an antibiotic that is less likely to have a long-term effect on the gut microbiota and applying the probiotic bacteria to prevent dysbiosis or to reestablish the gut microbiota after the antibiotic treatment (Browne, 2016; Wischmeyer et al., 2016). In the meantime, we should reduce the unnecessary oral administration

\section{REFERENCES}

Adams, K. N., Szumowski, J. D., and Ramakrishnan, L. (2014). Verapamil, and its metabolite norverapamil, inhibit macrophage-induced, bacterial efflux pump-mediated tolerance to multiple anti-tubercular drugs. J. Infect. Dis. 210, 456-466. doi: 10.1093/infdis/jiu095

Adams, K. N., Takaki, K., Connolly, L. E., Wiedenhoft, H., Winglee, K., Humbert, O., et al. (2011). Drug tolerance in replicating mycobacteria mediated by a macrophage-induced efflux mechanism. Cell 145, 39-53. doi: 10.1016/j.cell.2011.02.022

Akiyama, H., Ueda, M., Kanzaki, H., Tada, J., and Arata, J. (1997). Biofilm formation of Staphylococcus aureus strains isolated from impetigo and furuncle: role of fibrinogen and fibrin. J. Dermatol. Sci. 16, 2-10. doi: 10.1016/S0923-1811(97)00611-7

Amato, S. M., Orman, M. A., and Brynildsen, M. P. (2013). Metabolic control of persister formation in Escherichia coli. Mol. Cell 50, 475-487. doi: 10.1016/j.molcel.2013.04.002

Andersson, D. I., and Hughes, D. (2014). Microbiological effects of sublethal levels of antibiotics. Nat. Rev. Microbiol. 12, 465-478. doi: 10.1038/nrmicro3270

Bae, J., Oh, E., and Jeon, B. (2014). Enhanced transmission of antibiotic resistance in Campylobacter jejuni biofilms by natural transformation. Antimicrob. Agents Chemother. 58, 7573-7575. doi: 10.1128/AAC.04066-14

Baharoglu, Z., and Mazel, D. (2011). Vibrio cholerae triggers SOS and mutagenesis in response to a wide range of antibiotics: a route towards multiresistance. Antimicrob. Agents Chemother. 55, 2438-2441. doi: 10.1128/AAC.01549-10

Balaban, N. Q., Merrin, J., Chait, R., Kowalik, L., and Leibler, S. (2004). Bacterial persistence as a phenotypic switch. Science 305, 1622-1625. doi: $10.1126 /$ science. 1099390

Baquero, F. (2001). Low-level antibacterial resistance: a gateway to clinical resistance. Drug Resist. Updat. 4, 93-105. doi: 10.1054/drup.2001.0196

Baquero, F., Negri, M. C., Morosini, M. I., and Blazquez, J. (1998). Antibiotic-selective environments. Clin. Infect. Dis. 27(Suppl. 1), S5-S11. doi: $10.1086 / 514916$ of antibiotics to reduce the adverse effects of antimicrobial on gut microbiota. The specified use of bacterial molecules that bind to the specific innate immune receptors is also another strategy to rebuild the interactions altered by antibiotic treatment (Ubeda and Pamer, 2012). For a sustainable antibiotc treatment, the ideal drug should be hydrophilic, of relatively slow clearance, small volume of distribution and have minimal ecological impact on the animal commensal and environmental microbiomes. New, eco-friendly, veterinary AMDs can readily be developed from the currently used drug classes to provide a credible alternative agents (Toutain et al., 2016).

With an improved understanding on the interaction of antimicrobials, pathogens and host gut microbiota and immune response, we have reasons to believe that we will develop judicious antibiotic treatment strategies and better control programs to fight against microbial infections.

\section{AUTHOR CONTRIBUTIONS}

JL and SX wrote and revised the review. SA, FW, YG, CZ, XC, YW, and JC revised the review. GC contributed to the conception of the review and wrote the review.

\section{ACKNOWLEDGMENTS}

This work was supported by the National Natural Science Foundation of China (31502115).

Beaber, J. W., Hochhut, B., and Waldor, M. K. (2004). SOS response promotes horizontal dissemination of antibiotic resistance genes. Nature 427, 72-74. doi: $10.1038 /$ nature 02241

Becattini, S., Taur, Y., and Pamer, E. G. (2016). Antibiotic-induced changes in the intestinal microbiota and disease. Trends Mol. Med. 22, 458-478. doi: 10.1016/j.molmed.2016.04.003

Beer, J., Wagner, C. C., and Zeitlinger, M. (2009). Protein binding of antimicrobials: methods for quantification and for investigation of its impact on bacterial killing. AAPS J. 11, 1-12. doi: 10.1208/s12248-008-9072-1

Bergogne-Berezin, E. (2002). Clinical role of protein binding of quinolones. Clin. Pharmacokinet. 41, 741-750. doi: 10.2165/00003088-200241100-00004

Bernier, S. P., Lebeaux, D., DeFrancesco, A. S., Valomon, A., Soubigou, G., Coppee, J. Y., et al. (2013). Starvation, together with the SOS response, mediates high biofilm-specific tolerance to the fluoroquinolone ofloxacin. PLoS Genet. 9:e1003144. doi: 10.1371/journal.pgen.1003144

Blondeau, J. M. (2009). New concepts in antimicrobial susceptibility testing: the mutant prevention concentration and mutant selection window approach. Vet. Dermatol. 20, 383-396. doi: 10.1111/j.1365-3164.2009.00856.x

Brauner, A., Fridman, O., Gefen, O., and Balaban, N. Q. (2016). Distinguishing between resistance, tolerance and persistence to antibiotic treatment. Nat. Rev. Microbiol. 14, 320-330. doi: 10.1038/nrmicro.2016.34

Brestoff, J. R., and Artis, D. (2013). Commensal bacteria at the interface of host metabolism and the immune system. Nat. Immunol. 14, 676-684. doi: $10.1038 /$ ni. 2640

Brook, I. (1989). Inoculum effect. Rev. Infect. Dis. 11, 361-368. doi: 10.1093/clinids/11.3.361

Browne, H. (2016). Antibiotics, gut bugs and the young. Nat. Rev. Microbiol. 14:336. doi: 10.1038/nrmicro.2016.73

Bulitta, J. B., Yang, J. C., Yohonn, L., Ly, N. S., Brown, S. V., D’Hondt, R. E., et al. (2010). Attenuation of colistin bactericidal activity by high inoculum of Pseudomonas aeruginosa characterized by a new mechanism-based population pharmacodynamic model. Antimicrob. Agents Chemother. 54, 2051-2062. doi: 10.1128/AAC.00881-09 
Chambers, H. F., Mills, J., Drake, T. A., and Sande, M. A. (1984). Failure of a once-daily regimen of cefonicid for treatment of endocarditis due to Staphylococcus aureus. Rev. Infect. Dis. 6(Suppl. 4), S870-S874. doi: 10.1093/clinids/6.supplement_4.s870

Cheng, G., Dai, M., Ahmed, S., Hao, H., Wang, X., and Yuan, Z. (2016). Antimicrobial drugs in fighting against antimicrobial resistance. Front. Microbiol. 7:470. doi: 10.3389/fmicb.2016.00470

Cheng, G., Hao, H., Xie, S., Wang, X., Dai, M., Huang, L., et al. (2014). Antibiotic alternatives: the substitution of antibiotics in animal husbandry? Front. Microbiol. 5:217. doi: 10.3389/fmicb.2014.00217

Clinical and Laboratory Standards Institute (CLSI) (2011). Performance Standards for Antimicrobial Susceptibility Testing; 21th Informational Supplement. CLSI Document M100-S21. Wayne, PA: Clinical and Laboratory Standards Institute.

Cohen, N. R., Lobritz, M. A., and Collins, J. J. (2013). Microbial persistence and the road to drug resistance. Cell Host Microbe 13, 632-642. doi: 10.1016/j.chom.2013.05.009

Cox, L. M., Yamanishi, S., Sohn, J., Alekseyenko, A. V., Leung, J. M., Cho, I., et al. (2014). Altering the intestinal microbiota during a critical developmental window has lasting metabolic consequences. Cell 158, 705-721. doi: 10.1016/j.cell.2014.05.052

Czock, D., Markert, C., Hartman, B., and Keller, F. (2009). Pharmacokinetics and pharmacodynamics of antimicrobial drugs. Expert Opin. Drug Metab. Toxicol. 5, 475-487. doi: 10.1517/17425250902913808

Dalhoff, A. (2005). Immunomodulatory activities of fluoroquinolones. Infection 33(Suppl. 2), 55-70. doi: 10.1007/s15010-005-8209-8

Dietrich, L. E., Teal, T. K., Price-Whelan, A., and Newman, D. K. (2008). Redox-active antibiotics control gene expression and community behavior in divergent bacteria. Science 321, 1203-1206. doi: 10.1126/science. 1160619

Docobo-Perez, F., Lopez-Cerero, L., Lopez-Rojas, R., Egea, P., DominguezHerrera, J., Rodriguez-Bano, J., et al. (2013). Inoculum effect on the efficacies of amoxicillin-clavulanate, piperacillin-tazobactam, and imipenem against extended-spectrum beta-lactamase (ESBL)-producing and non-ESBLproducing Escherichia coli in an experimental murine sepsis model. Antimicrob. Agents Chemother. 57, 2109-2113. doi: 10.1128/AAC.02190-12

Dorr, T., Vulic, M., and Lewis, K. (2010). Ciprofloxacin causes persister formation by inducing the TisB toxin in Escherichia coli. PLoS Biol. 8:e1000317. doi: 10.1371/journal.pbio.1000317

Drlica, K. (2003). The mutant selection window and antimicrobial resistance. J. Antimicrob. Chemother. 52, 11-17. doi: 10.1093/jac/dkg269

Drlica, K., and Zhao, X. (2007). Mutant selection window hypothesis updated. Clin. Infect. Dis. 44, 681-688. doi: 10.1086/511642

Dykhuizen, R. S., Harvey, G., Stephenson, N., Nathwani, D., and Gould, I. M. (1995). Protein binding and serum bactericidal activities of vancomycin and teicoplanin. Antimicrob. Agents Chemother. 39, 1842-1847. doi: 10.1128/AAC.39.8.1842

Entenza, J. M., Giddey, M., Vouillamoz, J., and Moreillon, P. (2010). In vitro prevention of the emergence of daptomycin resistance in Staphylococcus aureus and enterococci following combination with amoxicillin/clavulanic acid or ampicillin. Int. J. Antimicrob. Agents 35, 451-456. doi: 10.1016/j.ijantimicag.2009.12.022

Estes, L. (1998). Review of pharmacokinetics and pharmacodynamics of antimicrobial agents. Mayo Clin. Proc. 73, 1114-1122. doi: 10.4065/73.11.1114

European Committee on Antimicrobial Susceptibility Testing (EUCAST) (2011). Breakpoint Tables for Interpretation of MICs and Zone Diameters. Version 1.3. European Committee on Antimicrobial Susceptibility Testing. Available online at: http://www.eucast.org

Faber, F., Tran, L., Byndloss, M. X., Lopez, C. A., Velazquez, E. M., Kerrinnes, T., et al. (2016). Host-mediated sugar oxidation promotes post-antibiotic pathogen expansion. Nature 534, 697-699. doi: 10.1038/nature18597

Fajardo, A., and Martinez, J. L. (2008). Antibiotics as signals that trigger specific bacterial responses. Curr. Opin. Microbiol. 11, 161-167. doi: 10.1016/j.mib.2008.02.006

Ferran, A. A., Kesteman, A. S., Toutain, P. L., and Bousquet-Melou, A. (2009). Pharmacokinetic/pharmacodynamic analysis of the influence of inoculum size on the selection of resistance in Escherichia coli by a quinolone in a mouse thigh bacterial infection model. Antimicrob. Agents Chemother. 53, 3384-3390. doi: 10.1128/AAC.01347-08
Ferran, A. A., Toutain, P. L., and Bousquet-Melou, A. (2014). Comparison of the reduction in the antibacterial potency of a fluoroquinolone conferred by a single mutation in the quinolone resistance-determining region or by the inoculum size effect. Int. J. Antimicrob. Agents 44, 472-474. doi: 10.1016/j.ijantimicag.2014.07.007

Ferran, A., Dupouy, V., Toutain, P. L., and Bousquet-Melou, A. (2007). Influence of inoculum size on the selection of resistant mutants of Escherichia coli in relation to mutant prevention concentrations of marbofloxacin. Antimicrob. Agents Chemother. 51, 4163-4166. doi: 10.1128/AAC.00156-07

Field, W., and Hershberg, R. (2015). Alarmingly high segregation frequencies of quinolone resistance alleles within human and animal microbiomes are not explained by direct clinical antibiotic exposure. Genome Biol. Evol. 7, 1743-1757. doi: 10.1093/gbe/evv102

Fleck, L. E., North, E. J., Lee, R. E., Mulcahy, L. R., Casadei, G., and Lewis, K. (2014). A screen for and validation of prodrug antimicrobials. Antimicrob. Agents Chemother. 58, 1410-1419. doi: 10.1128/AAC.02136-13

Francino, M. P. (2014). Early development of the gut microbiota and immune health. Pathogens 3, 769-790. doi: 10.3390/pathogens3030769

Francino, M. P. (2015). Antibiotics and the human gut microbiome: dysbioses and accumulation of resistances. Front. Microbiol. 6:1543. doi: $10.3389 /$ fmicb.2015.01543

Franzosa, E. A., Hsu, T., Sirota-Madi, A., Shafquat, A., Abu-Ali, G., Morgan, X. C., et al. (2015). Sequencing and beyond: integrating molecular 'omics' for microbial community profiling. Nat. Rev. Microbiol. 13, 360-372. doi: $10.1038 /$ nrmicro3451

Fridman, O., Goldberg, A., Ronin, I., Shoresh, N., and Balaban, N. Q. (2014). Optimization of lag time underlies antibiotic tolerance in evolved bacterial populations. Nature 513, 418-421. doi: 10.1038/nature13469

Furbeth, M., and Adam, D. (1976). The importance of serum components, particularly complement factors, properdin and transferrin, in inhibition of bacterial growth by human serum (author's transl). Infection 4, 102-106.

Gasparrini, A. J., Crofts, T. S., Gibson, M. K., Tarr, P. I., Warner, B. B., and Dantas, G. (2016). Antibiotic perturbation of the preterm infant gut microbiome and resistome. Gut Microbes 7, 443-449. doi: 10.1080/19490976.2016.1218584

Ghobrial, O., Derendorf, H., and Hillman, J. D. (2010). Human serum binding and its effect on the pharmacodynamics of the lantibiotic MU1140. Eur. J. Pharm. Sci. 41, 658-664. doi: 10.1016/j.ejps.2010.09.005

Ghosh, T. S., Gupta, S. S., Nair, G. B., and Mande, S. S. (2013). In silico analysis of antibiotic resistance genes in the gut microflora of individuals from diverse geographies and age-groups. PLoS ONE 8:e83823. doi: 10.1371/journal.pone.0083823

Gibson, M. K., Wang, B., Ahmadi, S., Burnham, C. A. D., Tarr, P. I., Warner, B. B., et al. (2016). Developmental dynamics of the preterm infant gut microbiota and antibiotic resistome. Nat. Microbiol. 1:16024. doi: 10.1038/nmicrobiol.2016.24

Girgis, H. S., Harris, K., and Tavazoie, S. (2012). Large mutational target size for rapid emergence of bacterial persistence. Proc. Natl. Acad. Sci. U.S.A. 109, 12740-12745. doi: 10.1073/pnas.1205124109

Gullberg, E., Cao, S., Berg, O. G., Ilback, C., Sandegren, L., Hughes, D., et al. (2011). Selection of resistant bacteria at very low antibiotic concentrations. PLoS Pathog. 7:e1002158. doi: 10.1371/journal.ppat.1002158

Gutierrez, A., Laureti, L., Crussard, S., Abida, H., Rodriguez-Rojas, A., Blazquez, J., et al. (2013). $\beta$-Lactam antibiotics promote bacterial mutagenesis via an RpoS-mediated reduction in replication fidelity. Nat. Commun. 4, 1610. doi: $10.1038 /$ ncomms 2607

Hall-Stoodley, L., Stoodley, P., Kathju, S., Hoiby, N., Moser, C., Costerton, J. W., et al. (2012). Towards diagnostic guidelines for biofilmassociated infections. FEMS Immunol. Med. Microbiol. 65, 127-145. doi: 10.1111/j.1574-695X.2012.00968.x

Hegde, S. S., Reyes, N., Wiens, T., Vanasse, N., Skinner, R., McCullough, J., et al. (2004). Pharmacodynamics of telavancin (TD-6424), a novel bactericidal agent, against gram-positive bacteria. Antimicrob. Agents Chemother. 48, 3043-3050. doi: 10.1128/AAC.48.8.3043-3050.2004

Helaine, S., Thompson, J. A., Watson, K. G., Liu, M., Boyle, C., and Holden, D. W. (2010). Dynamics of intracellular bacterial replication at the single cell level. Proc. Natl. Acad. Sci. U.S.A. 107, 3746-3751. doi: 10.1073/pnas.1000041107

Jarrell, A. S., Kruer, R. M., Johnson, D., and Lipsett, P. A. (2015). Antimicrobial pharmacokinetics and pharmacodynamics. Surg. Infect. 16, 375-379. doi: $10.1089 /$ sur.2014.180 
Johnson, P. J., and Levin, B. R. (2013). Pharmacodynamics, population dynamics, and the evolution of persistence in Staphylococcus aureus. PLoS Genet. 9:e1003123. doi: 10.1371/journal.pgen.1003123

Jones, R. N., and Barry, A. L. (1987). Antimicrobial activity of ceftriaxone, cefotaxime, desacetylcefotaxime, and cefotaxime-desacetylcefotaxime in the presence of human serum. Antimicrob. Agents Chemother. 31, 818-820. doi: 10.1128/AAC.31.5.818

Kabat, A. M., Srinivasan, N., and Maloy, K. J. (2014). Modulation of immune development and function by intestinal microbiota. Trends Immunol. 35, 507-517. doi: 10.1016/j.it.2014.07.010

Kaplan, N., Awrey, D., Bardouniotis, E., Berman, J., Yethon, J., Pauls, H. W., et al. (2013). In vitro activity (MICs and rate of kill) of AFN-1252, a novel FabI inhibitor, in the presence of serum and in combination with other antibiotics. J. Chemother. 25, 18-25. doi: 10.1179/1973947812Y.0000000063

Kesteman, A. S., Ferran, A. A., Perrin-Guyomard, A., Laurentie, M., Sanders, P., Toutain, P. L., et al. (2009). Influence of inoculum size and marbofloxacin plasma exposure on the amplification of resistant subpopulations of Klebsiella pneumoniae in a rat lung infection model. Antimicrob. Agents Chemother. 53, 4740-4748. doi: 10.1128/AAC.00608-09

Kester, J. C., and Fortune, S. M. (2014). Persisters and beyond: mechanisms of phenotypic drug resistance and drug tolerance in bacteria. Crit. Rev. Biochem. Mol. Biol. 49, 91-101. doi: 10.3109/10409238.2013.869543

Kim, J. S., Heo, P., Yang, T. J., Lee, K. S., Cho, D. H., Kim, B. T., et al. (2011). Selective killing of bacterial persisters by a single chemical compound without affecting normal antibiotic-sensitive cells. Antimicrob. Agents Chemother. 55, 5380-5383. doi: 10.1128/AAC.00708-11

Kohanski, M. A., DePristo, M. A., and Collins, J. J. (2010). Sublethal antibiotic treatment leads to multidrug resistance via radical-induced mutagenesis. Mol. Cell 37, 311-320. doi: 10.1016/j.molcel.2010.01.003

Korpela, K., Salonen, A., Virta, L. J., Kekkonen, R. A., Forslund, K., Bork, P., et al. (2016). Intestinal microbiome is related to lifetime antibiotic use in Finnish pre-school children. Nat. Commun. 7:10410. doi: 10.1038/ncomms10410

Lam, Y. W., Duroux, M. H., Gambertoglio, J. G., Barriere, S. L., and Guglielmo, B. J. (1988). Effect of protein binding on serum bactericidal activities of ceftazidime and cefoperazone in healthy volunteers. Antimicrob. Agents Chemother. 32, 298-302. doi: 10.1128/AAC.32.3.298

Lee, B. L., Sachdeva, M., and Chambers, H. F. (1991). Effect of protein binding of daptomycin on MIC and antibacterial activity. Antimicrob. Agents Chemother. 35, 2505-2508. doi: 10.1128/AAC.35.12.2505

Lee, H. H., Molla, M. N., Cantor, C. R., and Collins, J. J. (2010). Bacterial charity work leads to population-wide resistance. Nature 467, 82-85. doi: 10.1038/nature09354

Lewis, K. (2007). Persister cells, dormancy and infectious disease. Nat. Rev. Microbiol. 5, 48-56. doi: 10.1038/nrmicrol557

Lhermie, G., El Garch, F., Toutain, P. L., Ferran, A. A., and BousquetMelou, A. (2015). Bacterial species-specific activity of a fluoroquinolone against two closely related pasteurellaceae with similar mics: differential in vitro inoculum effects and in vivo efficacies. PLOS ONE 10:e0141441. doi: 10.1371/journal.pone.0141441

Liu, A., Fong, A., Becket, E., Yuan, J., Tamae, C., Medrano, L., et al. (2011). Selective advantage of resistant strains at trace levels of antibiotics: a simple and ultrasensitive color test for detection of antibiotics and genotoxic agents. Antimicrob. Agents Chemother. 55, 1204-1210. doi: 10.1128/AAC.01182-10

Lopez, E., and Blazquez, J. (2009). Effect of subinhibitory concentrations of antibiotics on intrachromosomal homologous recombination in Escherichia coli. Antimicrob. Agents Chemother. 53, 3411-3415. doi: 10.1128/AAC.00358-09

Lopez, E., Elez, M., Matic, I., and Blazquez, J. (2007). Antibiotic-mediated recombination: ciprofloxacin stimulates SOS-independent recombination of divergent sequences in Escherichia coli. Mol. Microbiol. 64, 83-93. doi: 10.1111/j.1365-2958.2007.05642.x

Macedo, N., Rovira, A., and Torremorell, M. (2015). Haemophilus parasuis: infection, immunity and enrofloxacin. Vet. Res. 46:128. doi: 10.1186/s13567-015-0263-3

Macpherson, A. J., Geuking, M. B., Slack, E., Hapfelmeier, S., and McCoy, K. D. (2012). The habitat, double life, citizenship, and forgetfulness of IgA. Immunol. Rev. 245, 132-146. doi: 10.1111/j.1600-065X.2011. 01072.x
Madar, D., Dekel, E., Bren, A., Zimmer, A., Porat, Z., and Alon, U. (2013). Promoter activity dynamics in the lag phase of Escherichia coli. BMC Syst. Biol. 7:136. doi: $10.1186 / 1752-0509-7-136$

Manina, G., Dhar, N., and McKinney, J. D. (2015). Stress and host immunity amplify Mycobacterium tuberculosis phenotypic heterogeneity and induce nongrowing metabolically active forms. Cell Host Microbe 17, 32-46. doi: 10.1016/j.chom.2014.11.016

Mascio, C. T., Alder, J. D., and Silverman, J. A. (2007). Bactericidal action of daptomycin against stationary-phase and nondividing Staphylococcus aureus cells. Antimicrob. Agents Chemother. 51, 4255-4260. doi: 10.1128/AAC.00824-07

Miyake, N., Kadowaki, M., Sato, Y., Eriguchi, Y., Nagasaki, Y., Harada, Y., et al. (2011). Influence of inoculum size on MICs for methicillin-susceptible Staphylococcus aureus and methicillin-resistant Staphylococcus aureus. Jpn. J. Antibiot. 64, 231-237.

Mizunaga, S., Kamiyama, T., Fukuda, Y., Takahata, M., and Mitsuyama, J. (2005). Influence of inoculum size of Staphylococcus aureus and Pseudomonas aeruginosa on in vitro activities and in vivo efficacy of fluoroquinolones and carbapenems. J. Antimicrob. Chemother. 56, 91-96. doi: 10.1093/jac/dki163

Mouton, J. W., Ambrose, P. G., Canton, R., Drusano, G. L., Harbarth, S., MacGowan, A., et al. (2011). Conserving antibiotics for the future: new ways to use old and new drugs from a pharmacokinetic and pharmacodynamic perspective. Drug Resist. Updat. 14, 107-117. doi: 10.1016/j.drup.2011.02.005

Nix, D. E., Matthias, K. R., and Ferguson, E. C. (2004). Effect of ertapenem protein binding on killing of bacteria. Antimicrob. Agents Chemother. 48, 3419-3424. doi: 10.1128/AAC.48.9.3419-3424.2004

Penesyan, A., Gillings, M., and Paulsen, I. T. (2015). Antibiotic discovery: combatting bacterial resistance in cells and in biofilm communities. Molecules 20, 5286-5298. doi: 10.3390/molecules20045286

Richie, D. L., Ghannoum, M. A., Isham, N., Thompson, K. V., and Ryder, N. S. (2012). Nonspecific effect of Mycograb on amphotericin B MIC. Antimicrob. Agents Chemother. 56, 3963-3964. doi: 10.1128/AAC.00435-12

Rio-Marques, L., Hartke, A., and Bizzini, A. (2014). The effect of inoculum size on selection of in vitro resistance to vancomycin, daptomycin, and linezolid in methicillin-resistant Staphylococcus aureus. Microb. Drug Resist. 20, 539-543. doi: $10.1089 / \mathrm{mdr} .2014 .0059$

Romero, D., Traxler, M. F., Lopez, D., and Kolter, R. (2011). Antibiotics as signal molecules. Chem. Rev. 111, 5492-5505. doi: 10.1021/cr2000509

Rutten, N. B., Rijkers, G. T., Meijssen, C. B., Crijns, C. E., Oudshoorn, J. H., van der Ent, C. K., et al. (2015). Intestinal microbiota composition after antibiotic treatment in early life: the INCA study. BMC Pediatr. 15:204. doi: 10.1186/s12887-015-0519-0

Sekirov, I., Russell, S. L., Antunes, L. C., and Finlay, B. B. (2010). Gut microbiota in health and disease. Physiol. Rev. 90, 859-904. doi: 10.1152/physrev.00045.2009

Smith, D. A., Di, L., and Kerns, E. H. (2010). The effect of plasma protein binding on in vivo efficacy: misconceptions in drug discovery. Nat. Rev. Drug Discov. 9, 929-939. doi: 10.1038/nrd3287

Stryjewski, M. E., Graham, D. R., Wilson, S. E., O’Riordan, W., Young, D., Lentnek, A., et al. (2008). Telavancin versus vancomycin for the treatment of complicated skin and skin-structure infections caused by gram-positive organisms. Clin. Infect. Dis. 46, 1683-1693. doi: 10.1086/587896

Tato, M., Lopez, Y., Morosini, M. I., Moreno-Bofarull, A., Garcia-Alonso, F., Gargallo-Viola, D., et al. (2014). Characterization of variables that may influence ozenoxacin in susceptibility testing, including MIC and MBC values. Diagn. Microbiol. Infect. Dis. 78, 263-267. doi: 10.1016/j.diagmicrobio.2013.11.010

Thi, T. D., Lopez, E., Rodriguez-Rojas, A., Rodriguez-Beltran, J., Couce, A., Guelfo, J. R., et al. (2011). Effect of recA inactivation on mutagenesis of Escherichia coli exposed to sublethal concentrations of antimicrobials. J. Antimicrob. Chemother. 66, 531-538. doi: 10.1093/jac/dkq496

Toutain, P. L., Ferran, A. A., Bousquet-Melou, A., Pelligand, L., and Lees, P. (2016). Veterinary medicine needs new green antimicrobial drugs. Front. Microbiol. 7:1196. doi: $10.3389 /$ fmicb.2016.01196

Turnidge, J., and Paterson, D. L. (2007). Setting and revising antibacterial susceptibility breakpoints. Clin. Microbiol. Rev. 20, 391-408. doi: 10.1128/CMR.00047-06

Tyerman, J. G., Ponciano, J. M., Joyce, P., Forney, L. J., and Harmon, L. J. (2013). The evolution of antibiotic susceptibility and resistance during the formation 
of Escherichia coli biofilms in the absence of antibiotics. BMC Evol. Biol. 13:22. doi: 10.1186/1471-2148-13-22

Ubeda, C., Maiques, E., Knecht, E., Lasa, I., Novick, R. P., and Penades, J. R. (2005). Antibiotic-induced SOS response promotes horizontal dissemination of pathogenicity island-encoded virulence factors in staphylococci. Mol. Microbiol. 56, 836-844. doi: 10.1111/j.1365-2958.2005. 04584.x

Ubeda, C., and Pamer, E. G. (2012). Antibiotics, microbiota, and immune defense. Trends Immunol. 33, 459-466. doi: 10.1016/j.it.2012.05.003

Udekwu, K. I., Parrish, N., Ankomah, P., Baquero, F., and Levin, B. R. (2009). Functional relationship between bacterial cell density and the efficacy of antibiotics. J. Antimicrob. Chemother. 63, 745-757. doi: 10.1093/jac/dkn554

Vasseur, M. V., Laurentie, M., Rolland, J. G., Perrin-Guyomard, A., Henri, J., Ferran, A. A., et al. (2014). Low or high doses of cefquinome targeting low or high bacterial inocula cure Klebsiella pneumoniae lung infections but differentially impact the levels of antibiotic resistance in fecal flora. Antimicrob. Agents Chemother. 58, 1744-1748. doi: 10.1128/AAC.02135-13

Wallinga, D., and Burch, D. G. (2013). Does adding routine antibiotics to animal feed pose a serious risk to human health? BMJ 347:f4214. doi: 10.1136/bmj.f4214

Wiegand, I., Hilpert, K., and Hancock, R. E. (2008). Agar and broth dilution methods to determine the minimal inhibitory concentration (MIC) of antimicrobial substances. Nat. Protoc. 3, 163-175. doi: 10.1038/nprot.2007.521

Wischmeyer, P. E., McDonald, D., and Knight, R. (2016). Role of the microbiome, probiotics, and 'dysbiosis therapy' in critical illness. Curr. Opin. Crit. Care 22, 347-353. doi: 10.1097/MCC.0000000000000321

Woodhead, M., Blasi, F., Ewig, S., Garau, J., Huchon, G., Ieven, M., et al. (2011). Guidelines for the management of adult lower respiratory tract infections-summary. Clin. Microbiol. Infect. 17(Suppl. 6), 1-24. doi: 10.1111/j.1469-0691.2011.03602.x

Yim, G., Wang, H. H., and Davies, J. (2007). Antibiotics as signalling molecules. Philos. Trans. R. Soc. Lond. B Biol. Sci. 362, 1195-1200. doi: $10.1098 /$ rstb.2007.2044
Yonezawa, H., Osaki, T., and Kamiya, S. (2015). Biofilm formation by Helicobacter pylori and its involvement for antibiotic resistance. Biomed. Res. Int. 2015:9. doi: 10.1155/2015/914791

Young, V. B., and Schmidt, T. M. (2004). Antibiotic-associated diarrhea accompanied by large-scale alterations in the composition of the fecal microbiota. J. Clin. Microbiol. 42, 1203-1206. doi: 10.1128/JCM.42.3.1203-1206.2004

Zamoner, W., de Freitas, F. M., Garms, D. S., de Oliveira, M. G., Balbi, A. L., and Ponce, D. (2016). Pharmacokinetics and pharmacodynamics of antibiotics in critically ill acute kidney injury patients. Pharmacol. Res. Perspect. 4:e00280. doi: $10.1002 /$ prp2.280

Zeitlinger, M. A., Derendorf, H., Mouton, J. W., Cars, O., Craig, W. A., Andes, D., et al. (2011). Protein binding: do we ever learn? Antimicrob. Agents Chemother. 55, 3067-3074. doi: 10.1128/AAC.01433-10

Zhanel, G. G., Saunders, D. G., Hoban, D. J., and Karlowsky, J. A. (2001). Influence of human serum on antifungal pharmacodynamics with Candida albicans. Antimicrob. Agents Chemother. 45, 2018-2022. doi: 10.1128/AAC.45.7.2018-2022.2001

Zhang, J., Xu, C., Shen, H., Li, J., Guo, L., Cao, G., et al. (2014). Biofilm formation in Haemophilus parasuis: relationship with antibiotic resistance, serotype and genetic typing. Res. Vet. Sci. 97, 171-175. doi: 10.1016/j.rvsc.2014.04.014

Conflict of Interest Statement: The authors declare that the research was conducted in the absence of any commercial or financial relationships that could be construed as a potential conflict of interest.

Copyright (c) 2017 Li, Xie, Ahmed, Wang, Gu, Zhang, Chai, Wu, Cai and Cheng. This is an open-access article distributed under the terms of the Creative Commons Attribution License (CC BY). The use, distribution or reproduction in other forums is permitted, provided the original author(s) or licensor are credited and that the original publication in this journal is cited, in accordance with accepted academic practice. No use, distribution or reproduction is permitted which does not comply with these terms. 